\title{
«No me acabo de desengañar si esta doncella está loca o endemoniada»: Análisis del episodio de la dama de verde, Isabela Catrucho (Persiles, III, XIX y XX-XXI)
}

\author{
Juan Ramón Muñoz Sánchez \\ Universidad de Córdoba \\ juanra92@hotmail.com
}

Recepción: 26/08/2016, Aceptación: 09/02/2017, Publicación: 22/12/2017

\section{Resumen}

En el siguiente estudio se pretende realizar un pormenorizado análisis del episodio de Isabela Castrucho y Andrea Marulo (Persiles, III, XIX y xx-XXI), al tiempo que se establecen sus relaciones intratextuales con el resto de la producción literaria de Cervantes.

Palabras clave

Cervantes; episodio; ambigüedad; ironía; amor

\begin{abstract}
"No me acabo de desengañar si esta doncella está loca o endemoniada": Analysis of the episode of Isabela Castrucho, the lady in green (Persiles, III, XIX and XX-XXI)

This study seeks to analyze in detail the episode of Isabela Castrucho and Andrea Marulo (Persiles, III, XIX and XX-XXI), while establishing the intra-textual relations it maintains with the remaining literary output of Cervantes.
\end{abstract}

Keywords

Cervantes; episode; ambiguity; irony; love 
Los trabajos de Persiles y Sigismunda, historia septentrional (Madrid, 1617) se conforma alrededor de dos elementos que determinan su tema y su composición: el amor y las aventuras viajeras. En efecto, la historia de los virtuosos amantes Periandro y Auristela no es sino la búsqueda de una ortodoxia de los sentimientos, con una fuerte tonalidad moral de trasfondo de corte neoplatónico, luego de haberse originado un conflicto que es el responsable de poner en marcha la acción de la novela. Periandro se enamora de Auristela, y su amor, por las circunstancias en la que se genera -ella está destinada a ser la esposa de su hermano mayor, el príncipe Magsimino de Tule_, los obliga, instigados por su madre, la reina Eustoquia, que, al favorecer al segundón, obra en flagrante perjuicio de su primogénito, a emprender un viaje que es al mismo tiempo una huida, disfrazado de un «voto de venir a Roma a enterarse ella de la fe católica, que en aquellas partes setentrionales andaba un poco en quiebra, jurándole primero Persiles que en ninguna manera iría en dicho ni en hecho contra su honestidad» (Cervantes, Los trabajos de Persiles y Sigismunda, IV, XII, 703). Durante el trayecto, a causa de su portentosa belleza y de los múltiples vaivenes de la fortuna, así como a veces de sus propios procederes — como los prontos celosos de Auristela—, se ven envueltos en un laberinto de aventuras y peligros que pone en jaque sus vidas lo mismo que su amor, y del que salen triunfadores gracias a su tenacidad y fidelidad amorosas, a su carácter paciente y sufriente, al uso de la mentira, el engaño y el disfraz y a su confianza en la Divina Providencia. Pero que no son sino los necesarios trabajos que han de padecer para acrisolarse y hacerse acreedores de la dicha y la felicidad final que sella su unión. De modo que su proceloso viaje deviene una peregrinación de perfección amorosa y espiritual en permanente roce con el mundo, con diferentes modelos sociales y con numerosos casos de amor de naturaleza dispar.

El viaje de Periandro y Auristela, como se sabe, comprende el agitado y dilatado itinerario que separa la isla semilegendaria de Tule de la ciudad de Roma, el cual se desarrolla de norte a sur por los gélidos mares septentrionales del continente europeo, repletos de islas, en su mayoría, fantásticas e incidentes varios, y de oeste a este por los polvorientos caminos meridionales de los países latinos, con sus ciudades y villas, sus ventas y mesones, sus casas y centros de devoción, su realidad ambiental y circunstancial a cuestas.

El camino por tan vasto mapa se corresponde con el intento de Cervantes de conformar la novela total, aquella que, simultáneamente, atendiera a la relación del género humano con la divinidad y explorara el problemático existir de los hombres en la historia, en la sociedad y consigo mismo. Para conseguir tamaño propósito, el autor se vio en la obligación de tener que completar la trama que vertebra la novela con la interpolación de una galería de episodios que diera cuenta de aquello que es territorio vedado en la acción medular. Siempre fiel a la tradición, Cervantes encontró la sanción de este modelo estructural en la antigüedad grecolatina así como en la teoría y en la práctica literaria de su tiempo; pero siempre nuevo y original, fue un paso más allá por la cantidad de relatos 
que incorpora, lo que no respondía sino al intento experimental de combinar el vanguardista concepto de épica en prosa, renovado al calor de la exhumación y difusión de la novela helenística signada en la Historia etiópica de Heliodoro, con la novela corta. De tal suerte que en el Persiles, aun más que en Don Quijote de la Mancha, confluyen todos los géneros narrativos del periodo, al tiempo que se entreveran diferentes estilos, registros, niveles de escritura y personajes, pero perspicazmente combinados y armonizados en tanto que se produce una ponderada adecuación de fondo y forma.

Empero, el Persiles no es únicamente la narración de una historia que aspira a cifrar en sus páginas el universo todo, sino también una reflexión sobre la literatura, sobre el estatuto ficcional de la propia obra, por lo que resulta ser, como Don Quijote y el entramado novelesco de El casamiento engañoso y El coloquio de los perros, una metanovela. Pues, efectivamente, al lado de la materia narrativa, y como complemento diegético y juego literario, se introducen comentarios y lucubraciones teóricas que inciden sobre la acción contada, ya para justificarla, ya para, no sin ironía, ponerla en solfa. Como cabía esperar, el precepto (neo) aristotélico de la variedad en la unidad suscita no pocas intervenciones directas del narrador externo en forma de reflexiones metanarrativas, que, sin embargo, se pueden condensar en una sola:

Las peregrinaciones largas siempre traen consigo diversos acontecimientos y, como la diversidad se compone de cosas diferentes, es forzoso que los casos lo sean. Bien nos lo muestra esta historia, cuyos acontecimientos nos cortan su hilo, poniéndonos en duda dónde será bien anudarle; porque no todas las cosas que suceden son buenas para contadas y podrían pasar sin serlo y sin quedar menoscabada la historia. Acciones hay que, por grandes, deben callarse y otras que, por bajas, no deben decirse, puesto que es excelencia de la historia que cualquiera cosa que en ella se escriba puede pasar, al sabor de la verdad que trae consigo; lo que no tiene la fábula, a quien conviene guisar sus acciones con tanta puntualidad y gusto, y con tanta verisimilitud, que, a despecho y a pesar de la mentira, forme una verdadera armonía. (III, x, 526-527) ${ }^{1}$

\section{Una aproximación al libro III de Los trabajos de Persiles y Sigismunda}

El libro III del Persiles ${ }^{2}$ comprende la práctica totalidad del viaje terrestre de los héroes de la novela, pues comienza con la llegada de Periandro, Auristela y la familia del español Antonio a Lisboa y concluye en la ciudad italiana de Luca,

1. Sobre estas cuestiones y otras que abordaremos a continuación, véase Muñoz Sánchez (2015a).

2. Véase, por ejemplo, Romero Muñoz (2004: 37-42); Lozano Renieblas (1998: 111-117, 121 124 y 171-188); Deffis de Calvo (1999: 82-96); Rey Hazas y Sevilla Arroyo (1999: XX-XLV); Baquero Escudero (2013: 173-195); Canavaggio (2014: 235-251); Muñoz Sánchez (2015b). 
muy cerca de Roma, la meta de la peregrinación. El camino por una geografía reconocible y familiar, frente a la parte septentrional, supone la práctica desaparición de las aventuras vinculadas al espacio marino, imaginario y ajeno: ya no hay tormentas, naufragios, raptos, añejas profecías, crueles sacrificios, terribles experiencias que amenazan la vida, piratas, bárbaros salvajes, etc.; aunque los héroes se verán envueltos en situaciones apremiantes y no faltarán las falsas muertes, ya no volverán a separarse. Su tránsito es, por consiguiente, mucho más reposado y tranquilo, máxime cuando viajan desembarazados de pretendientes amorosos que turben su sosiego, entereza y fidelidad amorosa. ${ }^{3}$ Signo de ese viraje es el cambio de indumentaria de los héroes, que abandonarán sus exóticas vestimentas originarias por el hábito de peregrinos, cuyo motivo principal no es otro que el intento de pasar inadvertidos en su trayecto hacia Roma. Es preciso matizar que el entorno identificable lo es para el escritor, que ve coartada su libertad ficcional, e igualmente para el lector; no en cambio para los protagonistas, todos ellos nacidos en el norte de Europa, excepción hecha del español Antonio. De manera que su viaje deviene una especie de recorrido turístico, ${ }^{4}$ si bien muy especial en razón de que, más que pasar por las grandes urbes del presente contemporáneo, lo que realizan es un viaje a través de la historia romano-visigoda de la zona, ${ }^{5}$ que, ya en Francia e Italia, se desarrolla por la "vía francigena» o peregrinatio maior, ${ }^{6}$ de conocimiento y aprendizaje. Este hecho, unido a la disminución considerable de las peripecias, acarrea que Periandro y compañía mantengan cierta distancia ante lo que observan, que su papel en no pocas ocasiones no sea más que el de espectadores de un mundo que desconocen y están descubriendo y asimilando o identificando con lo leído en libros. ${ }^{7}$

3. Así, comenta Aurora Egido: «el amor de Periandro y Auristela apenas si cuenta en su paso por Portugal y España, sino los sucesos que acontecen en su peregrinar» (1994: 262).

4. De hecho, Lozano-Renieblas indica que el itinerario meridional equivale a "lo que hoy llamaríamos rutas turísticas [...], todos los lugares están ordenados en el camino de acuerdo con el referente real y siguiendo las recomendaciones de las guías» (1998: 115).

5. Nerlich señala que «el mapa que Cervantes pone ante nuestros ojos no es de la España de Felipe III, sino el mapa histórico de la España antigua y visigoda, por ejemplo el que publicó Abraham Ortelius, aleccionado por Arias Montano, en 1586 [...] El camino que toman los viajeros llegados del septentrión corresponde a la vía romana que lleva de Lisboa a Narbona, pasando por Toledo, Valencia, Barcelona (y Perpiñán, que todavía no se llamaba así)» (2005: 161).

6. Scaramuzza Vidoni señalaba que la ruta meridional de Lisboa a Roma es deudora de «la llamada literatura odepórica»; un viaje que se desarrolla «en la península ibérica a lo largo de caminos bien definidos, y después en Francia e Italia, en el eje de la peregrinatio maior, la 'vía francigena' que llegaba hasta Roma y después proseguía siempre por tierra hasta Bari, donde los peregrinos se embarcaban a Jerusalén" (1998: 148-149).

7. Así, a causa de que «las lecciones de libros muchas veces hacen más cierta esperiencia de las cosas que no las tienen los mismos que las han visto, a causa de que el que lee con atención repara una y muchas veces en lo que va leyendo, y el que mira sin ella no repara en nada, y, con esto, excede la lección a la vista» (III, viII, 505), Periandro realiza, al paso por el Tajo y Toledo, el elogio del río y de la ciudad, cantados por el «jamás alabado como se debe poeta Garcilaso de la Vega» (III, viII, 504), antes que un español, vecino del Quintanar, como Antonio el padre. 
Por otro lado, frente al zigzagueante y nebuloso viaje por las aguas del Atlántico norte del libro I y al estatismo de los libros II y IV, que se desarrollan en su práctica totalidad en derredor de un espacio único: la isla del rey Policarpo y Roma, respectivamente, el itinerario terrestre del libro III presenta un esquema completamente lineal: el del camino. El cual, conforme a la idoneidad de la estructura itinerante, facilita tanto los encuentros causales como la diversidad social, ${ }^{8}$ e igualmente las detenciones en determinadas poblaciones, en ventas, mesones o posadas, en casas particulares y en algún que otro templo. De modo que la ausencia de aventuras y el papel de espectadores ante un mundo ajeno de los héroes se suple, merced al esquema lineal del camino, con la variedad episódica, con el incesante surgimiento de episodios narrativos, que, de algún modo, refieren y reflejan la circunstancia social y ambiental del lugar en el cual se desarrollan. Es conveniente señalar, empero, que no todas las paradas engendran historias laterales, puesto que algunas no son sino el recibimiento y el agasajo que se dispensa al escuadrón de peregrinos "peregrinos", como sucede, pongamos, durante la permanencia de los héroes en la casa del Corregidor de Badajoz (III, II). Hay que tener en consideración, además, que las sucesivas escalas del viaje en casas, ventas o poblaciones desempeñan el propósito de ir sembrando la fama de los protagonistas, de la que se hará eco el príncipe Arnaldo cuando recorra punto por punto el mismo itinerario, a la par que ir allanando futuros acontecimientos que se desgranarán en el libro IV, como lo concerniente al retrato de Auristela que pinta de memoria el acechador de bellezas del duque de Nemurs (III, XIII). Con todo, la mayor parte de los altos y de los encuentros principian una historia particular, ${ }^{9}$ si exceptuamos la detención del grupo en el Quintanar de la Orden en casa de Diego de Villaseñor (III, Ix), en donde se culmina, con la vuelta a casa, el episodio del espańol Antonio; así como cuando se combinan los dos elementos, de forma que los relatos subordinados comienzan con un encuentro en el camino y prosiguen, de seguida o más tarde, con la detención de los héroes en un espacio concreto. ${ }^{10}$

8. Recuérdese que Bajtín argumentaba que «el 'camino' es el lugar de preferencia de los encuentros causales. En el camino [...], en el mismo punto espacial y temporal, se intersectan los caminos de gente de todo tipo: de representantes de todos los niveles y estratos sociales, de todas las religiones, de todas las nacionalidades, de todas las edades [...] Aquí se combinan, de una manera original, las series espaciales y temporales de los destinos y vidas humanos, complicándose y concertándose por las distancias sociales, que en este caso están superadas [...] El camino es especialmente adecuado para la presentación de un acontecimiento dirigido por la casualidad [...] Así se hace claro el importante papel temático del camino en la historia de la novela» (1989: 394). 9. Como sucede en los episodios de Mari Cobeña y Tozuelo (III, viII), de los falsos cautivos (III, x), de Rafala (III, XI), del mesón de Perpiñán (III, XIII), de Claricia y Domicio (III, XIV-XV) y de Ruperta y Croriano (III, XVI-XVII).

10. Así, en los episodios de Feliciana de la Voz y Rosiano (III, II-V), de Ortel Banedre y Luisa (III, VI-VII, XVI, XVIII-XIX), de Ambrosia Agustina (III, XI y XIII) y de Isabela Castrucho (III, XIX $\mathrm{y} \mathrm{xX}-\mathrm{xxI})$. 
La composición del libro III se suele distribuir en dos secciones delimitadas geográficamente: ${ }^{11}$ por un lado, la parte del camino que transcurre en los reinos peninsulares (III, I-XII); por otro, la que se desarrolla en territorio francés e italiano (III, XIII-XXI). Como motivos se aducen que los peregrinos se limitan a ser los espectadores de excepción de las historias que se desencadenan en la monarquía hispánica, mientras que se implican hasta la médula en las de las comarcas francoitalianas; que a su paso por España el grupo de peregrinos no se modifica, justo lo contrario de lo que sucede en Francia, en donde el escuadrón se va engrosando con la incorporación de nuevos personajes; que el tono marcadamente realista o costumbrista de los sucesos acaecidos en suelo espańol se muda, nada más adentrarse en el país galo, por otro que tensa al límite el principio de la verosimilitud; que si desde Lisboa hasta Perpiñán el grupo camina a pie, a partir de Francia, en concreto desde la casa de Claricia, lo harán a caballo.

Pese a que esta compartimentación resulta muy sugerente, principalmente por el notable viraje que experimenta la narración con el paso del suelo español al francés, en relación sobre todo con el tipo de verosimilitud que opera en cada territorio, así como porque el conflicto medular empieza a recuperar cierta primacía narrativa, en lo demás cabe poner no pocas objeciones. Por lo pronto, el escuadrón de romeros sí sufre alteraciones en su conformación durante el trayecto por la península ibérica, por cuanto Antonio el padre y Ricla detienen su andadura en el Quintanar, en donde, a las dos parejas de hermanos, la fingida de Periandro y Auristela y la verdadera de Antonio el hijo y Constanza, se les une Bartolomé el manchego al cuidado del bagaje, quien después protagonizará su propia historia al lado de Luisa la talaverana. Y lo mismo sucede en lo concerniente a la actuación y vinculación de los héroes en las diversas historias. Es verdad que la implicación de los peregrinos varía de unos sucesos y episodios a otros, pero no que se registre una nítida demarcación en su comportamiento entre España y Francia-Italia. Ellos son los depositarios del hijo y de las joyas de Rosanio y aceptan a Feliciana de la Voz como compañera de peregrinaje, aunque sean los pastores de la majada y los dos caballeros trujillenses los que humana y activamente se impliquen en el caso de amor de los jóvenes extremeños; se ven envueltos, sin querer, en la muerte de don Diego de Parraces en una floresta extremeña; Periandro aconseja ilustradamente a Ortel Banedre a propósito del matrimonio cristiano para que no castigue, sino que perdone a Luisa por el adulterio perpetrado; el episodio de los falsos cautivos es más eficaz con la presencia de los peregrinos, habida cuenta de que su cabal significación se halla precisamente en el contraste de sus respectivos lienzos, uno apócrifo y otro verdadero, es decir: en la confrontación, desde el ámbito de la pintura y en satisfacción del lema horaciano del ut pictura poiesis, de la poesía y la historia, de la ficción y la vida; se pone en peligro su integridad en la razia turco-berberisca del episodio de Rafala; ya en Francia,

11. Véase, por ejemplo, Romero (2004: 38-40), Lozano-Renieblas (1998: 114-117) y Rey Hazas y Sevilla Arroyo (1999: XXX-XXXVI). 
Periandro, por un lado, y Antonio el hijo, por otro, salvan a los vástagos de Claricia y a Feliz Flora, respectivamente, poniendo en peligro su vida; Constanza, en cuanto tesorera del grupo, muestra su caridad con el preso que resultará ser Ambrosia Agustina, lo mismo que con la familia del pobre que se juega la libertad a cambio de la manutención de sus hijos y su mujer en el mesón de Perpiñán, mientras que, como adivina, reconoce a Luisa la talaverana, a la que aceptan en su grupo en una posada francesa; Auristela, Constanza, Ruperta y Feliz Flora, por fin, ayudan en lo que pueden a Isabela Castrucho para que su historia de amor arribe a buen puerto. Su participación en los distintos episodios y sucesos, si bien en distintos grados, se da, por consiguiente, igual en España que en Francia e Italia. Es más, en las dos únicas historias en las que su intervención se reduce exclusivamente a la de meros concurrentes de excepción son en la de Mari Cobeña y Tozuelo, acaecida en La Sagra de Toledo, y en la de Ruperta y Croriano, que ha lugar en un mesón de la dulce Francia, solo que se extrema en el caso de los escoceses puesto que ni siquiera ofician como espectadores en el desenlace. Quizá no esté de más recordar que la participación de los héroes principales de la novela y sus dos acompañantes, los hermanos Antonio y Constanza, en los episodios no es menos activa en el libro III que en los anteriores; no constituye justamente un factor distintivo, ya que hay casos en los que su labor no sobrepasa la de ser meros receptores orales de biografías ajenas. ${ }^{12}$

La morfología del libro III es la más elástica, excéntrica, abierta y variada de Los trabajos de Persiles y Sigismunda, a causa tanto de la proliferación de secuencias narrativas laterales como de la inusitada carencia de relieve diegético de la historia principal. Ello se debe a que, como reconocía el Pinciano en el progreso del nudo y el desenlace narrativos, "parece imposible en obras largas ir siempre apretando sin quebrar» (Philosophía antigua poética, 213). Mas igualmente a la intención del autor de querer referir y reflejar críticamente, a la manera del Quijote y de las Novelas ejemplares, la situación histórico-social de la monarquía hispánica. De modo que, a través de los episodios, encara y pasa revista a los problemas contemporáneos más acuciantes, desde el matrimonio cristiano, la honra social y la situación de la mujer, hasta el alojamiento obligado de los tercios en los pueblos, villas y lugares, las delicadas relaciones hispano-turcas y la expulsión de los moriscos; poniéndolos ante los ojos de los amantes nórdicos, los cuales pueden constatar de primera mano que los males y pesares de los hombres en los modelos sociales tenidos por bárbaros no son desemejantes de los de los reinos peninsulares y, por extensión, de los civilizados y católicos países del mediodía europeo. No de otro modo, la «alma ciudad de Roma» a la que arribarán fulgirá antes por ser el reino de la corrupción, la prostitución, la superstición y la vanidad que el cielo de la tierra. ${ }^{13}$

12. Como sucede en los episodios de Rutilio (I, viII-IX), Manuel de Sosa (I, x), Sulpicia (II, XIV) y Renato y Eusebia (II, XIX-XXI).

13. Véase, desde diversas perspectivas, Pelorson (2003: 49-58), Redondo (2004: 91), Armstrong-Roche (2009: 33-110), Canavaggio (2014: 250-251) y Ghia (2015). 
No obstante lo dicho, la cohesión de la materia narrativa del libro III se mantiene gracias a la rica variedad de modos de engarce que ensaya el escritor a la hora de integrar las distintas secuencias narrativas secundarias y a la vinculación temática que mantienen tanto entre sí como con respecto a la trama primera. Dos son los temas que se repiten con mayor frecuencia: el perdón de las ofensas y el amor. El primero es observable en el episodio de Feliciana, en el de Ortel Banedre, en el incidente que acaba con la vida del conde marido de Constanza, en el de Ambrosia Agustina y en el de Ruperta. El segundo, aparte de mostrar sus varias caras, se ramifica en una multiplicidad de subtemas relacionados, como el matrimonio, la libertad de los hijos a la hora de escoger cónyuge, la aceptación del cuerpo y el sexo, la inserción de los amantes en el ciclo de la vida, la autodeterminación de la mujer, etc., los cuales de un modo u otro afecta a la mayoría de las historias.

Un ejemplo que ilustra lo dicho lo constituye el episodio de Isabela Castrucho y Andrea Marulo. Pues, efectivamente, su historia de amor, como veremos detalladamente, no se engarza en la trama primera sino siguiendo el principio compositivo expuesto bajo las leyes que operan en el viaje terrestre por el Mediodía europeo (un encuentro y un alto en el camino); su justificación viene dada por vinculación temática, a través del diálogo que mantiene tanto con la historia principal como con parte de la materia narrativa interpolada. Sin embargo, más allá del Persiles, el episodio novelesco manifiesta una tupida red de nexos intratextuales con el resto de la producción literaria de Cervantes, como veremos a continuación.

\section{Análisis estructural y temático del episodio de Isabela Castrucho}

El episodio de Isabela Castrucho y Andrea Marulo se articula en torno a dos impulsos narrativos, que, segmentados por el relato de primer grado, y conforme a su índole dispar, lo estructuran en dos partes nítidamente diferenciadas. El primero, acaecido en el capítulo xIX, es una acción mostrada en el presente narrativo de la novela, cuya construcción gira alrededor del motivo de un encuentro en el camino: el de un grupo de ocho personas a caballo y un rezagado con el escuadrón de peregrinos a la salida de la cueva de Soldino; su función no es otra que la de principiar la historia con la presentación no menos sesgada que enigmática así de la protagonista como del conflicto. El segundo, que comprende los capítulos XX y XXI, tiene lugar poco tiempo después en un espacio diferente; su irrupción en la fábula se debe a la detención del viaje de los peregrinos en su marcha hacia Roma por la llegada a uno de los lugares y de las edificaciones que lo jalonan: la posada de Luca. Representa la parte principal del episodio por cuanto es donde alcanza su desarrollo narrativo completo. Su morfología, habida cuenta de la mixtura que exhibe de narración y acción, es bastante más compleja que la primera; si bien prepondera la presentación viva de los acontecimientos sobre los contados, la combinación de los dos elementos sirve para delimitar la trama de esta segunda parte en dos, que se avienen con los capítulos xx y xxI. Aunque el capítulo xx es principalmente una acción mostrada, se recurre, debido a la distorsión cronológica de la secuencia episódica, que da co- 
mienzo in medias res por el nudo de la historia, al proceso activador de la memoria ${ }^{14}$ para exponer los antecedentes del caso mediante la relación homodiegética-intradiegética explicativa de un personaje, Isabela; el XXI, por su parte, es la prosecución del nudo y el desenlace representados en el plano básico de los acontecimientos generales. Después, ya en el capítulo I del libro IV, se registra una muletilla final en que los personajes principales comentan, sin enjuiciarlo, el episodio.

La disposición fragmentaria de la secuencia episódica en dos impulsos narrativos, como hemos comentado, es recurrente a lo largo del libro III. Pero es con el episodio de Ambrosia Agustina (XI y XII) con el que más paralelismos guarda: en ambos casos la historia se inicia con el misterioso encuentro en el camino de los amantes nórdicos y sus acompañantes con la protagonista (Ambrosia, Isabela), sobre la cual ofrece un testimonio incompleto y recóndito un informador (el soldado a caballo y uno de los arcabuceros, el rezagado); continúa tiempo después con su llegada a una población (Barcelona, Luca) y su detención en ella en un espacio concreto (la casa de Ambrosia, la posada de Luca). Por supuesto que entre ambos episodios hay diferencias importantes, en especial en lo que respecta al desarrollo de la historia, ya que es más enrevesada la acción de Luca que la de Barcelona, la cual básicamente se reduce al relato primopersonal de Ambrosia Agustina, dado que al arribar a las playas de la ciudad condal su caso ya está concluido, de modo que la parte final da comienzo in extremas res, al contrario que la de Isabela que lo hace in medias res. El mismo esquema de inserción exhibe el episodio del italiano Rutilio (I, vi y vIII-IX), en virtud de que su historia se divide, primero, en su presentación indirecta por varios prisioneros de la isla mazmorra y, después, en el cuento de su vida contando por él mismo, a instancias del español Antonio, en el marco de la isla despoblada. Este modelo de articulación estructural de un relato subordinado en la fábula ya había sido ensayado por Cervantes, en sus líneas mayores, con anterioridad. El primer ejemplo lo constituye el episodio trágico de Lisandro y Leonida de La Galatea (libro I), pues se compone igualmente de una acción mostrada en la diégesis que se suspende para ser continuada por extenso un poco después; solo que cambian los elementos, pues no irrumpe en la trama pastoril mediante un encuentro como en los casos de Ambrosia e Isabela, sino con una acción que se corresponde con el desenlace de la historia: la muerte a cuchillo de Carino por Lisandro, presenciada por los pastores Elicio y Erastro; luego, sucede la relación homodiegética-intradiegética de Lisandro para explicar las circunstancias de su caso a Elicio, tras encontrarse en una floresta a mitad de la noche. La forma de la segunda parte del episodio de Lisandro es la misma que la de Ambrosia Agustina, puesto que prácticamente ambas son de naturaleza narrativa. En El ingenioso caballero don Quijote de la Mancha se registran dos casos de parecido acoplamiento técnico. El primero de ellos es el episodio de los alcaldes rebuznadores (xxIv, XXV y xXvII). Como se recordará, el relato

14. Sobre este aspecto en el Persiles, véase Aurora Egido (1994: 285-306) y, desde otro ángulo, Lozano-Renieblas (2014: 101-116). 
subordinado empieza igual que los de Ambrosia e Isabela: un encuentro en el camino de los héroes principales con uno o varios de los personajes episódicos (en este caso, el cruce de don Quijote y Sancho con el joven que porta las lanzas y las alabardas); continúa con la detención de los héroes en un espacio único (aquí con la llegada a la venta de Maese Pedro), donde se cuenta la historia, los antecedentes del caso. La diferencia está en que el desenlace de este episodio quijotesco está separado narrativamente del relato homodiegético. Esto es, el episodio se dispone en tres impulsos narrativos diferentes delimitados por la trama medular. Con todo, el esquema resultante es muy parecido al de la historia de Isabela: encuentro-narración intradiegética-acción. El segundo de ellos es el episodio del morisco Ricote y su hija Ana Félix (LIV, LXIII y LXV). De vuelta de su aventura del gobierno de la Ínsula Barataria al castillo de los duques, Sancho se topa en el camino con un grupo de falsos peregrinos, siendo reconocido por uno, que resulta ser Ricote, el tendero morisco de su aldea, con el que habla afectuosamente, intercambian informaciones a propósito de sus singladuras y, luego, se despiden. Esto es, se repite el motivo del encuentro, pero ahora la diferencia radica en que, a causa del conocimiento y familiaridad de los encontrados, se trata de un proceso de agnición. Tiempo después, cuando don Quijote y Sancho son recibidos con los más altos honores y homenajeados en el puerto de Barcelona por los próceres de la ciudad, el episodio prosigue con la llegada intempestiva de Ana Félix en un bajel turco en el que, disfrazada de varón, oficia de arráez; la bella morisca cuenta las particularidades de su caso, al tiempo que se reencuentra con Ricote, su padre, que, por puro azar narrativo, se halla a la sazón en tal lugar. De modo y manera que al encuentro de Ricote y Ana Félix le sigue, con la llegada y estancia de los personajes principales a una población, una narración homodiegética. Lo que ocurre es que, como en el episodio de los alcaldes rebuznadores, el desenlace acaece en otro golpe narrativo distinto y separado por la acción primera. Pero en lo básico presenta el mismo esquema que el episodio de Isabela y Andrea. Todos estos ejemplos, en definitiva, responden al mismo patrón morfológico de engarce y desarrollo de un episodio sobre la fábula que le sirve de marco, solo que Cervantes hace variar la forma de unos casos a otros, experimenta con distintas posibilidades combinatorias que inciden en la particularidad de cada uno dentro del conjunto. No repite; se reescribe.

\section{El anuncio de un nuevo episodio: el encuentro con el grupo de la dama de verde}

A punto de abandonar la prodigiosa cueva de Soldino para encaminarse a Roma por el derrotero que les ha indicado el sabio astrólogo español, ${ }^{15}$ el hermoso es-

15. Nerlich (2005: 472-500) opina que, en la figura de Soldino, Cervantes rinde un caluroso homenaje al humanista extremeño Benito Arias Montano. Sin embargo, desde nuestro punto de vista, Soldino es deudor del venerable anciano que, en la Gerusalemme liberata (1581) de Torquato Tasso 
cuadrón de peregrinos se topa con un grupo de personas, del que sobresale, por su atavío, una dama:

Estando en esto, vieron venir por el camino y pasar por delante dellos hasta ocho personas a caballo, entre las cuales iba una mujer sentada en un rico sillón y sobre su mula, vestida de camino, toda de verde, hasta el sombrero, que con ricas y varias plumas azotaba el aire, con un antifaz, asimismo verde, cubierto el rostro. (III, XIX, 605-606)

Dado que se trata de una acción directa, la presentación del grupo y de la dama de verde le corresponde al narrador extradiegético-heterodiegético del Persiles; mas no la efectúa desde una posición de omnisciencia, sino que se acerca a sus personajes principales, se pone a su mismo nivel de conocimiento de los hechos o parte de una posición de aquiescencia para describir la escena. La utilización de este recurso por parte del narrador sirve para crear y potenciar expectación y suspense en los personajes, lo mismo que en lector, en tanto que la información que se brinda es la misma que tienen los personajes principales de la novela, y podemos adelantar que esta será la tónica de todo el episodio. De hecho, para la presentación del encuentro, el narrador utiliza a los personajes en la función narrativa de reflectores («estando en esto, vieron»). No parece impertinente señalar que esta perspectiva narrativa o modo de decir del narrador es la que prevalece a lo largo de todo el libro III del Persiles. Así, pongamos por caso, los puntos de vista del narrador, de los personajes y del lector están estrechamente ligados en los prolegómenos del episodio de Feliciana de la Voz, con esos encuentros misteriosos y llegadas intempestivas en las tinieblas de la noche; y lo mismo sucede en la historia de Ruperta, cuando la bellísima viuda escocesa, en la soledad de la cámara en que se aloja en un mesón de la dulce Francia, es espiada por los peregrinos repetir y renovar el juramento de venganza ante la calavera de la cabeza de su esposo en la caja de plata en que la porta, la espada con que fue asesinado y la camisa con la sangre aun no enjuta de él. Pero la utilización de los héroes en la función de reflectores de lo narrado se registra también en otros hechos, como en la descripción de las ermitas en las que viven, apartados del mundo, los franceses Renato y Eusebia, en el libro II. ${ }^{16}$ Lejos del Persiles, esta técnica deviene fundamental en las dos partes del Quijote - recuérdense los preliminares del episodio de Cardenio en que don Quijote y Sancho descubren, primero, un cojín y una maleta con cuatro camisas de delgada Holanda, otras cosas de lienzo, un pañizuelo con cien escudos de oro y un librillo de memoria ricamente guarnecido, después, a un hombre desnudo, desgreñado y descalzo saltando de risco en risco y de mata en mata, y, por fin, una mula muerta caída

—a quien se rinde tributo en el Persiles—, informa a los paladines cristianos, Carlos y Ubaldo, cómo liberar a Rinaldo de la isla jardín de las delicias de la maga sarracena Armida (canto XIV).

16. Véase Muñoz Sánchez (2008: 216-217). 
en un arroyo- y en la mayoría de las Novelas ejemplares, tales como Rinconete y Cortadillo, Las dos doncellas, La señora Cornelia y la bilogía El casamiento engañoso-El coloquio de los perros. Tampoco falta en La Galatea, sobre todo en el principio de las historias intercaladas, como sucede en el asesinato de Carino a manos de Lisandro que presencian Elicio y Erastro o en la boda secreta de Rosaura y Grisaldo que espían Galatea, Florisa y Teolinda. Además de para crear tensión dramática y suspensión en el lector, la postura de aquiescencia del narrador, por la que humaniza su saber, y la utilización de los personajes en calidad de reflectores de los hechos narrados, aunque no siempre, cumple el propósito de mostrar una acción incierta que necesita ser interpretada tanto a nivel diegético por los personajes implicados como fuera del texto por parte del lector, al modo - avant la lettre - de las novelas policíacas y detectivescas.

Ello nos sirve para enlazar con el otro aspecto fundamental de la descripción narrativa del encuentro: la dama vestida de verde. En la tradición folclórica y literaria el color verde se asocia con el amor, el erotismo, la sensualidad, la fertilidad y la esperanza. Pero en la obra de Cervantes, que se complace sobremanera de servirse del color verde, adquiere, aparte de esas, ${ }^{17}$ otra dimensión o se carga de una simbología distinta. Helena Percas de Ponseti (1975: II, 386-395, p. 394), que dedica unas páginas al análisis funcional del verde en el Quijote, llega a la conclusión de que simboliza «la profunda autodecepción del hombre cuando se aparta de lo propio o natural». Francisco Márquez Villanueva (1975: 147227 y 1995: 23-57), en dos estudios fundamentales, asocia el color verde con la locura, la estulticia y la bufonería, aspectos esenciales en la conformación de la literatura moderna, donde el entretenimiento y la risa cobran valor estético. En nuestro caso es indudable que el verde representa tanto al amor, sin excluir el sexo, y la esperanza como a la locura, emparentada con el engaño y el fingimiento. Si bien, no debe olvidarse que en la época los vestidos de camino eran justamente de colores vivos y llamativos.

Lo más extraordinario del encuentro, en función de la inaudita curiosidad que experimentan todos los personajes cervantinos por los sucesos, las cosas y las personas desconocidas, es que los peregrinos no medien palabra con los hombres a caballo y la dama de verde: «Pasaron por delante dellos y, con bajar las cabezas, sin hablar palabra alguna, los saludaron y pasaron de largo; los del camino tampoco hablaron palabra y al mismo modo les saludaron» (III, XIX, 606).

Sin embargo, todo se resuelve porque uno de los acompañantes del grupo de la dama, que se había quedado rezagado, enlaza con nuestro escuadrón de romeros, a los que solicita un poco de agua. Es ahora cuando el grupo principal inquiere información sobre "qué gente era la que iba allí delante, y qué dama la de lo verde» (III, xIx, 606). Conviene destacar que el rol de informador o el

17. De hecho, D. de Armas Wilson (1991: 223-247), en su estudio del episodio, entiende que el verde, en Isabel, simboliza la fertilidad. 
papel de personaje informante en los episodios del libro III del Persiles es de uso frecuente. Martina informa a Ortel Banedre acerca de Luisa y su circunstancia; el soldado a caballo y uno de los seis arcabuceros a pie son los que cuentan lo que saben a propósito del prisionero del carro que es Ambrosia Agustina; es la joven morisca Rafala la que advierte a los peregrinos de las intenciones reales de su tío; la singladura de Ruperta la refiere su anciano escudero; Soldino es el encargado de señalar a los peregrinos que Luisa y Bartolomé se han escapado juntos, así como de indicarles otras informaciones relevantes que afectan al desenlace de la historia principal. Se trata de otra estrategia narrativa que Cervantes venía ensayando desde La Galatea, como lo corrobora el papel diegético que desempeña la joven Maurisa, encargada de exponer diversos sucesos de los episodios de Teolinda y Leonarda y de Rosaura y Grisaldo. En el Ingenioso hidalgo, el papel de informador lo encarnan el cabrero Pedro, en la secuencia episódica de Marcela, y el innominado de Sierra Morena que relaciona las pistas diseminadas de la maleta, el salvaje desgreńado y la mula muerta y las articula en un discurso en que relata a don Quijote y Sancho lo que sabe a cuenta del «Roto de la Mala Figura» desde su arribada a Sierra Morena, en el episodio de Cardenio. En el Ingenioso caballero, tal función la desempeñan el estudiante que profiere la historia de Basilio, Quiteria y Camacho, y el joven del pueblo de los alcaldes rebuznadores. El grado de información que ofrecen estos personajes es sumamente variable; oscila desde lo superficial y lo básico o elemental hasta conocer los pormenores de los hechos de primera mano al haberlos presenciado como testigo. En la mayoría de los casos, las informaciones que brindan estos personajes, amén de para presentar las distintas historias o para revelar nuevos datos sobre el curso de su desarrollo, sirve para mostrar cada caso desde distintas perspectivas o puntos de vista, que ora se concatenan complementariamente, ora entran en confrontación dialéctica.

El informante de la historia de Isabela Castrucho, habida cuenta de que la ignora en su conjunto, de que desconoce los pormenores del caso, apunta únicamente la razón de ser del tío y de la sobrina, así como el motivo por el que estima que ella camina tal cual va:

El que allí va delante es el señor Alejandro Castrucho, gentilhombre capuano y uno de los ricos varones no solo de Capua, sino de todo el reino de Nápoles. La dama es su sobrina, la señora Isabela Castrucho, que nació en España, donde deja enterrado a su padre, por cuya muerte su tío la lleva a casar a Capua, y, a lo que yo creo, no muy contenta. (III, XIX, 606)

El anciano escudero de Ruperta, representante y valedor de las férreas normas sociales clasistas establecidas, no entiende que una mujer pueda ir descontenta al matrimonio, pues no es otro el motivo de su existencia que «enterarse con la mitad que le falta, que es su marido» (III, xIx, 606). Sin embargo, el informante, que no está al tanto de las motivaciones internas de los personajes de los que habla y no comprende "esas filosofías» de las que trata el escudero, se 
limita a repetir lo que ha podido constatar desde que viaja con el grupo: que la joven «va triste» (III, XIx, 606).

Aun cuando la información deparada no es mucha, en los preliminares del episodio, como es norma en la obra de Cervantes, se consignan en síntesis sus temas más importantes: el deseo de completud, de integridad, tras su hallazgo, de la mitad perdida, emparentado, naturalmente, con la filosofía platónica del eros expuesta en el Banquete, singularmente en el discurso de Aristófanes a propósito del mito del hombre esférico, y en el Fedro, y con su interpretación y puesta al día por los grandes tratados filográficos del Renacimiento, ${ }^{18}$ y la decisión de la elección del cónyuge que enfrenta a los padres o familiares tutores y a los hijos o tutorados, que apunta a la dimensión social del sacramento del matrimonio regulado por el Decreto Tametsi, así como a la emancipación de la mujer.

Tras la pesquisa manifestada por el rezagado, el episodio queda suspendido a favor de la trama primera, que es la que se focaliza en la narración.

\section{Un alto en el camino en una posada de Luca: la extrańa aventura de la bella endemoniada}

Con la arribada del escuadrón de peregrinos a la ciudad italiana de Luca, el narrador externo del Persiles, que a lo largo del libro III entra y sale de la narración a su antojo, introduce un comentario por el cual advierte directamente al lector de que «aquí aconteció a nuestros pasajeros una de las más estrañas aventuras que se han contado en todo el discurso deste libro» (III, XIX, 611). La intromisión, susceptible de ser interpretada como una captación de benevolencia, es ambigua en su manifestación por cuanto, antes que anunciar la prosecución del episodio, parece alertar sobre un hecho que les sucederá a los protagonistas de la novela; es decir, efectúa una llamada de atención sobre el lector, pero sin revelarle el misterio. En todo caso, es indubitable que es el narrador externo el responsable de marcar la transición entre los relatos del primer y segundo grado, entre la diégesis y la metadiégesis. Es conveniente subrayar, empero, que, a pesar de que la mayor parte de la historia es una acción mostrada en directo que recae, en consecuencia, bajo su dominio, se mantendrá neutro, objetivo e impasible; se limitará sin más a sus funciones narrativa y rectora, en tanto montador de secuencias y organizador del discurso, pero mediatizadas por la visión y el grado de conocimiento que tendrán los personajes principales que se involucren en la trama episódica. De tal modo que estos, en función de espectadores de excepción de las acciones más que de reflectores de lo narrado, se convierten en los receptores implícitos y en guías del lector externo, dotando al relato de una visualidad tal, que le confiere cierta dramatización dinámica

18. Sobre el eros platónico, véase Muñoz Sánchez (2012: 99-183); sobre su desarrollo histórico desde la Antigüedad hasta el Siglo de Oro, Serés (1996); sobre su influencia determinante en el episodio de Isabel y a lo largo del Persiles, De Armas Wilson (1991: 223-247). 
de teatro dentro del teatro; ${ }^{19}$ con ello, lógicamente, persigue mantener intacto el interés del lector externo y provocar que se implique activamente en lo narrado, así como para que se dé cuenta y sepa apreciar los cambios de efecto, las estrategias narrativas puestas en juego, la habilidad y el ingenio del escribidor.

Que los actores principales de la novela y el lector van a ir de la mano se confirma nada más llegar los primeros a una de las posadas de Luca, puesto que, «al entrar, vio la señora Ruperta que salía un médico (que tal le pareció en el traje), diciendo a la huéspeda de la casa (que también le pareció no podía ser otra)» (III, XX, 611) que no puede determinar con seguridad si la señora que se hospeda está endemoniada o loca o ambas cosas a la vez. Con su peculiar juego de ambigüedades y de inversiones dialécticas, Cervantes establece un indicio que vincula el encuentro que tuvieron los peregrinos con los hombres a caballo que escoltaban a la dama y esta señora endemoniada o loca, ya que la relación entre la vestimenta verde de aquella, tan minuciosamente descrita, y la locura de esta es evidente, conforme a que "el verde es la indumentaria emblemática del loco» (Márquez Villanueva, 1995: 36). Solo que la locura de Isabela no es más que fingimiento, una ingeniosa impostura con la que poder conducir sus amores a buen término, vadeando, en su camino, cuantos obstáculos se interpongan en su consecución. ${ }^{20}$ Además de ser, no sin ironía, el símbolo o la metáfora de la pasión que la embarga, calificada como tal por la filosofía platónica. Por si no fuera suficiente, en las palabras del médico se cuela otro indicio más, cual es la relación de parentesco que une a la endemoniada o loca con un tío suyo: «con todo eso, tengo esperanza de su salud, si es que su tío no se da priesa en partirse» (III, xx, 611).

No obstante, estos nexos narrativos que enlazan una parte del episodio con la otra se les escapan a los peregrinos, que se enzarzan en una conversación con la ventera sobre si conviene o no detenerse en una posada en que se aloja una endemoniada. Por supuesto que la posadera los anima para que pasen y vean un espectáculo incomparable en cien leguas a la redonda, y, si no, «vénganse conmigo $[. .$.$] y verán lo que verán y dirán lo que yo digo» (III, xx, 612). Cualquiera$ recelaría de que la ventera está al tanto de la bufonada y el embeleco de Isabela. En fin, guiados por ella, entran en un cuarto

donde vieron echada en un lecho dorado a una hermosísima muchacha, de edad, al parecer, de diez y seis o diez y siete años. Tenía los brazos aspados y atados con unas vendas a los balaustres de la cabecera del lecho, como que le querían estorbar el moverlos a ninguna parte; dos mujeres, que debían de servirla de enfermeras, andaban buscándole las piernas para atárselas también. (III, xx, 612)

19. Sobre este aspecto ha llamado la atención Stanislav Zimic (2005: 179-185) en el análisis que efectúa del episodio de Isabela Castrucho; al punto de que en el Apéndice II transforma el episodio en una pieza dramática intitulada Entremés de la amante endemoniada (215-228).

20. Así lo señala Aurora Egido: «conviene situar [...] el episodio en la tradición literaria de la locura simulada con fines amorosos» (1991: 266). 
La segunda presentación de Isabela, en una situación harto diferente, no es tampoco motivo suficiente para que los peregrinos hilen una con otra y caigan en la cuenta de que se trata de la misma mujer, puede que a causa de que en la primera ocasión la loca de Luca llevaba el rostro velado por un «antifaz, asimismo verde». ${ }^{21}$

Michael Nerlich, en el sugerente análisis que realiza del episodio de Isabela, advierte de que «de este 'escuadrón' no vemos, en cuanto llegan al 'mesón', más que a las damas, mientras que los hombres son invisibles aunque - de acuerdo con la lógica - deben estar alli» (2005: 525). Ello se debe al ensalzamiento de lo femenino, a que el episodio de Isabela versa sobre «la lucha por la autodeterminación de la mujer». ${ }^{22} \mathrm{Y}$ efectivamente son solo los personajes femeninos del escuadrón, y no todos, los que observan las locuras demoniacas de Isabela y a los que esta apela y dirige sus palabras, no inocentes, sino densamente cargadas de segundas intenciones, aunque aun crípticas, pero que inciden en ese juego tan cervantino de mezclar las burlas con las veras, lo fingido con lo verdadero, el parecer con el ser:

¡Figuras del cielo, ángeles de carne! Sin duda, creo que venís a darme salud, porque de tan hermosa presencia y de tan cristiana visita no se puede esperar otra cosa. Por lo que debéis a ser quien sois, que sois mucho, que mandéis que me desaten; que con cuatro o cinco bocados que me dé en el brazo, quedaré harta y no me haré más mal, porque no estoy tan loca como parezco, ni el que me atormenta es tan cruel que dejará que me muerda. (III, xx, 612)

Es ahora, una vez que Isabela pide que la dejen a solas con las recién llegadas, cuando su tío — cuyo papel en esta historia es semejante al que desempeña el escudero enlutado en la de Ruperta: ser el representante de los valores tradiciones de la sociedad patriarcal — ${ }^{23}$ confirma que su sobrina no es otra que «la gentil dama de lo verde que, al salir de la cueva del sabio español, habían visto pasar por el camino, que el criado que se quedó atrás les dijo que se llamaba Isabela Castrucha y que se iba a casar al reino de Nápoles» (III, xx, 612-613).

21. Cervantes, como hemos repetido en otros lugares y como sucede ahora con Isabela, se complace en presentar a sus personajes en situaciones efectistas que denotan a un tiempo su caracterización etopéyica y el estado en el que se encuentran. Piénsese, por ejemplo, en la que hemos mencionado de Cardenio como el "Roto de la Mala Figura»; o en la de su compañera de fatigas, Dorotea, transmudándose, ante los ojos fascinados del cura y el barbero, de bellísimo galán a tierna doncella cabe el remanso de una fuente en Sierra Morena; o en la de los canes Cipión y Berganza haciéndose cruces por hablar y razonar como seres humanos, en El coloquio de los perros; o en la de Claudia Jerónima, en tropel encima de un caballo, vestida de mancebo a lo bandolero con dagas y espadas doradas, con dos pistolas a cada lado y empuñando una escopeta pequeña, en la segunda parte del Quijote; o en la de Luisa la talaverana, acoceada por Alonso, tras haber entrado en un mesón limpia y aseada cual nueva Venus oliendo a un pardo lleno de flores en el mes de mayo, haberse acercado a él y haberle dicho alguna picardía al oído, en el Persiles.

22. Sobre el papel fundamental que cumple lo femenino en el Persiles, aparte del estudio citado de Diana de Armas (1991), véase Scaramuzza Vidoni (1998: 185-216).

23. Cf. Muñoz Sánchez (2007). 
Precisada la conexión entre los dos puntos discontinuos en que se desarrolla la historia, solo falta saber la causa del conflicto que tiene postrada en cama a la dama de verde para que se reúnan los requisitos mínimos que permitan la recuperación de su pasado y disparen la historia. Antes de exponer su caso realiza Isabela una demostración de fuerza de su demonomanía:

Sentose Isabela como pudo en el lecho y, dando muestras de que quería hablar de propósito, rompió la voz con un tan grande suspiro, que pareció que con él se le arrancaba el alma; el fin del cual fue tenderse otra vez en el lecho y quedar desmayada, con señales tan de muerte, que obligó a los circunstantes a dar voces pidiendo un poco de agua para bañar el rostro de Isabela. (III, xx, 613)

Una de las características fundamentales de la producción literaria de Cervantes, especialmente a partir de El ingenioso hidalgo don Quijote de la Mancha, lo constituye la deliberada ambigüedad creadora que todo lo envuelve; la cual, unida a los cambios de efecto, la ironía y la infidencia autorial, comporta no pocas controversias críticas, si bien es la responsable de que su obra permanezca viva y sea siempre actual. ¿Simula Isabela estar bajo la posesión del demonio? $¿ \mathrm{O}$, como afirma Michael Nerlich (2005: 529-534), siguiendo la estela interpretativa abierta por Maurice Molho (1994: 53-54), tiene en realidad el demonio dentro, que no sería sino el fruto de su unión carnal con Andrea Marulo? ¿Es este desmayo que le sobreviene fingido o se trata de la inminencia del parto? Resulta difícil llegar a una solución definitiva —y quizá sea innecesario hacerlo habida cuenta de que transita en el filo del «todo puede ser»—. Lo que parece innegable es que esta escena es igual de sutil, oblicua y resbaladiza que aquella de El curioso impertinente en que la adúltera Camila representa para su marido escondido el papel de esposa virtuosa, hasta el punto de que, para asombro de los que estaban al tanto del simulacro, se hiere a sí misma, creándoles la incertidumbre de si obra astuta o sinceramente. El artificio, el engaño, la simulación, el teatro, la comedia, la farsa, la burla, el embeleco, el ingenio, la destreza, de todos modos, no son sino las armas de las que se valen los personajes cervantinos que intentan sobreponer su voluntad y su libertad a la coerción de la sociedad, sea del signo que sea; son los instrumentos que demuestran que su verdadera fuerza moral reside en el uso de la inteligencia y el ingenio y los que les proporcionan el triunfo sobre el cálculo, el interés y la norma.

Sucede, sin embargo, que el desmayo de Isabela propicia la entrada de su tío, «llevando una cruz en la mano y, en la otra, un hisopo de agua bendita» (III, XX, 613), objetos religiosos indispensables para combatir las posesiones demoniacas $\mathrm{u}$ oficiar los exorcismos, ${ }^{24}$ que, junto con la presencia de los dos sacerdotes, no pueden sino retrotraernos al que el ama y la sobrina de don Quijote piden al cura

24. Véase Hasbrouck (1992). 
y al barbero que hagan de la biblioteca de su señor y su tío. ${ }^{25}$ Objetos y presencias que la endemoniada desecha y desprecia, pues nada pueden hacer, solo la llegada de Andrea Marulo, hijo de un caballero de Luca llamado Juan Bautista Marulo, y su voluntad le sacarán de su enajenación.

Por lo tanto, una vez que se han trabado las dos partes del episodio, la del camino con la que transcurre en la posada de Luca, y que se han despejado todas las incógnitas, que Isabela es llevada por su tío a Capua a desposarse contra su voluntad, que a la altura de Luca le sobreviene la posesión demoniaca que la postra en cama y que solamente la arribada de un joven lucano estudiante en Salamanca, Andrea Marulo, y su voluntad podrán sacarla de su enajenación, se hace necesaria la relación intradiegética que hile y organice el conjunto, que recomponga organizadamente las piezas fragmentarias de tan sutil rompecabezas.

En efecto, nada más quedarse a solas por segunda vez con Auristela, Constanza, Ruperta y Feliz Flora, Isabela cuenta su caso. Como la mayor parte de los personajes que se ven en la tesitura de tener que rendir cuentas de su peripecia biográfica, «la bella endemoniada» principia su relato ab ovo:

Yo, señoras, soy la infelice Isabela Castrucha, cuyos padres me dieron nobleza; la fortuna, hacienda y, los cielos, algún tanto de hermosura. Nacieron mis padres en Capua, pero engendráronme en Espańa, donde nací y me crié en casa de este mi tío que aquí está, que en la corte del emperador la tenía. (III, xx, 614)

Una vez establecidas las coordenadas fundamentales que la ubican en el mundo y en la sociedad, Isabela, como cualquier relator en primera persona, selecciona las vivencias que estima inexcusables para valorar su estado presente. De manera que centra la exposición de su caso en torno a un aspecto único: su enamoramiento para con Andrea Marulo. Esto es, no cuenta toda su vida, como era (y es) norma en los libros de memorias y en novelas autobiográficas al modo del Libro de la vida de Teresa de Cepeda y del Lazarillo de Tormes y su progenie, sino una pequeña parte de ella, aunque sea la más importante. Este hecho, lógicamente, se adecua perfectamente a la situación de urgencia en la que se genera. Isabela, que busca la complicidad y ayuda de las peregrinas, no puede demorarse en otros detalles más que en los esenciales para que comprendan (y con ellas el lector) su situación presente — «iVálame Dios, y para qué tomo yo tan de atrás la corriente de mis desventuras!» (III, $\mathrm{xx}, 615)$ - Este modelo de relación intradiegética pura, evidentemente, no es nuevo en la obra de Cervantes, dado que la de Isabela se inserta en el último episodio interpolado de Cervantes, por lo que remite a un corpus granado de historias con la que formalmente se empareja: así, la narración de Rosaura a Galatea y Florisa en $\mathrm{La}$ Galatea; la de dońa Clara de Viedma a Dorotea en la Primera parte del Quijote; la

25. Sobre este celebérrimo pasaje quijotesco y su relación con el Santo Oficio, véase Gilman (1993: 146 y ss.). 
de Teodosia a su hermano don Rafael y la de Leocadia a Teodoro que es Teodosia en Las dos doncellas; la de Cornelia a los caballeros vascos don Juan y don Antonio en La señora Cornelia; la de la hija de don Diego de la Llana a Sancho, el escribano y el mayordomo, y la de Ana Félix al general de las galeras y demás, en el Quijote de 1615; la de Sulpicia a Periandro y sus marineros, la de Feliciana a los peregrinos y los pastores, la de Ambrosia Agustina a Constanza, Auristela, Periandro y Antonio y la de Claricia a las tres damas francesas en el Persiles. No faltan tampoco este tipo de narraciones en primera persona en el teatro cervantino, como lo corroboran la de Margarita a Arlaxa en El gallardo español; la del innominado personaje de la «dama» a Lugo en El rufián dichoso; y la de Camilo, que es Julia, a Manfredo en El laberinto de amor. Dentro del corpus, la narración de Isabela está más estrechamente ligada a las de dońa Clara, Cornelia y Feliciana que a las demás, en virtud de que son relatos de índole explicativa de sus respectivos casos de amor aun en curso, a la par que constituyen una petición de ayuda a sus interlocutores.

Prosigue su relación Isabela haciendo hincapié en un aspecto que sus acompañantes ya sabían por la información prestada por el rezagado: que es huérfana y que quedó bajo la tutela de su tío. Como se sabe, la orfandad, ya sea parcial — generalmente la de madre, por cuanto la autoridad familiar recaía en el padre- o total, es un aspecto habitual en la literatura áurea, sobre todo en la comedia nueva y en la novela corta, como generador de conflictos. En la obra de Cervantes, los casos más próximos al de Isabela son los de la pastora Marcela, en el Ingenioso hidalgo, el de la señora Cornelia, en la novela homónima, el de Margarita, en El gallardo español, y el de Ambrosia Agustina, en el Persiles, pues todas ellas son huérfanas cuyo patrimonio y cuidado se deja a cargo de un familiar más o menos próximo: un tío o un hermano, y todas, por ello, se ven abocadas a tener que reafirmar su voluntad y libertad a la hora de elegir cónyuge frente a las aspiraciones de su tutor. Los casos de Marcela e Isabela son los más afines entre sí, al punto de mantener una particular relación de reescritura por la que se ofrecen dos variaciones de una misma circunstancia: las dos son huérfanas de padre y madre, las dos son ricas herederas y jóvenes extraordinariamente hermosas, las dos quedan bajo la protección de un tío; pero, mientras que el de la pastora tiene en consideración el parecer de su sobrina en lo tocante a la elección de esposo, «sin tener ojo a la ganancia y granjería que le ofrecía el tener la hacienda de la moza dilatando su casamiento» (Don Quijote de la Mancha, I, XII, 142), ${ }^{26}$ el de la loca de Luca pretende desposarla por imposición con un primo suyo, "hombre no de mi gusto ni de mi condición», para que "la hacienda se quedase en casa» (III, xx, 615).

26. Recuérdese que este tipo de situación es una de las que cita y comenta Guzmán en su misógina diatriba contra el mal hacer de las mujeres en lo que respecta al matrimonio: «Otras lo hacen, que no tienen padres, por salir de las manos de sus tutores, creyendo que con ellos están vendidas y robadas» (Mateo Alemán, Guzmán de Alfarache, II, III, III, 647). 
El hecho es que la dama de verde se enamora ardorosamente de un joven caballero recién llegado a la corte, al que «miré en la iglesia de tal modo, que en casa no podía estar sin mirarle, porque quedó su presencia tan impresa en mi alma, que no la podía apartar de mi memoria» (III, xx, 615). Ni que decir se tiene que la terminología que emplea Isabela para anotar la impresión o la huella psíquica que deja la contemplación de la belleza deriva en último término de la doctrina de Paltón, del flujo de la pasión erótica expuesta por Sócrates en la palinodia del Fedro, divulgada, después, por el neoplatonismo, por Ficino, León Hebreo, Pietro Bembo o Castiglione, y trivializada y manoseada por la lírica amatoria y otros géneros de entonces; en Cervantes, como es norma, siempre lejos de la abstracción teórica, se incardina en el acontecer particular de un caso concreto. El entusiasmo que subyuga a Isabela da pronto paso a la resolución de adoptar la iniciativa, haciendo buena aquella pregunta que se recoge y se contesta en El laberinto de amor: «Di, ¿no puede acontecer, / sin admiración que asombre, / que una mujer busque a un hombre, / como un hombre a una mujer?» (II, 1146-1149). Isabela no es, desde luego, el primer personaje femenino de la obra de Cervantes en enamorarse antes que el hombre, como tampoco lo es en pretender ganarse la voluntad del que, sin tener conocimiento de ello, la ha rendido. Del mismo metal son, pongamos por caso, Teolinda en La Galatea, Leocadia en Las dos doncellas, Margarita en El gallardo español, Julia y Porcia en El laberinto de amor, Sinforosa y Ruperta en el Persiles; si bien, Isabela, por su carácter decidido y despachado, por su rebosante vitalidad, destreza, alegría, desparpajo e ingenio, por las indagaciones que realiza sobre su amado - las que no hicieron el alférez Campuzano y Estefanía de Caicedo del otro en El casamiento engañoso-, se asemeja a la gitanilla Preciosa. A ello hay que sumar el espacio urbano, la Villa y Corte, en que se desenvuelven; es más, las referencias de Isabela a misivas, entrevistas y conversaciones de amor en iglesias y centros de devoción, a miradas tan ocultas como parleras, no remiten sino al universo de la comedia urbana de ambientación contemporánea, que, en la obra de Cervantes, perdida $L a$ confusa, representa La entretenida. Como quiera que sea, Isabela, emulando el ejemplo de sus antecesoras, busca y encuentra la manera de poner en ejecución su deseo:

Finalmente, no me faltaron medios para entender quién él era, y la calidad de su persona, y qué hacía en la corte, o dónde iba; y lo que saqué en limpio fue que se llamaba Andrea Marulo, hijo de Juan Bautista Marulo, caballero desta ciudad, más noble que rico, que iba a estudiar a Salamanca. En seis días que allí estuvo tuve orden de escribirle quién yo era, y la mucha hacienda que tenía, y que de mi hermosura se podía certificar viéndome en la iglesia. (III, xx, 615)

Isabela apremia a Andrea para que se conozcan y no desperdicie la ocasión que se le ofrece, habida cuenta de que su tío pretende desposarla con un primo suyo de Capua. Como se sabe, el 11 de noviembre de 1563 se aprobó, durante la sesión XXIV del Concilio de Trento (1545-1563), el Decreto Tametsi, la disposición conciliar que prohibía los matrimonios secretos o clandestinos, al reglamentar la forma de su celebración del matrimonio según un rito que pres- 
cribía la presencia de un clérigo y de tres testigos, luego de la publicación de otras tantas proclamas; lo que significaba la restauración de la autoridad familiar en las bodas, su dimensión social, y la presencia necesaria de la iglesia, en cuanto institución moral a la par que civil, en la vida cotidiana de las gentes. Pese a ello, los matrimonios clandestinos siguieron practicándose y siendo válidos si eran sexualmente sancionados. Cervantes recrea en numerosas ocasiones y desde diversos enfoques el conflicto entre el amor franco de dos jóvenes y las pretensiones conyugales de los padres o familiares, o sea la dialéctica entre la naturaleza y la cultura o la norma. Las historias más significativas para nuestro caso son las siguientes: la del duque de Ferrara y Cornelia en La señora Cornelia; la de Dagoberto y Rosamira en El laberinto de amor; la de Clemente y Clemencia en Pedro de Urdemalas; la de Basilio y Quiteria en el Ingenioso caballero; el entrelazado de Carino, Leoncia, Solercio y Selviana, y la de Feliciana de la Voz y Rosanio en el Persiles. Sucede que en todas ellas los padres o la autoridad familiar competente conciertan los matrimonios de sus vástagos sin conocer sus sentimientos y al margen de su voluntad; mientras que los hijos, a sus espaldas, se las ingenian como pueden para imponer su gusto. Con todo, se pueden establecer dos grupos: por un lado, las historias en que el amor de los jóvenes se ratifica mediante la conmemoración de un casamiento por apretón de manos, seguido de su consumación (duque de Ferrara y Cornelia, Feliciana y Rosanio); por otro, aquellas en que se impone el deseo de los hijos a las intenciones de los padres, merced a ardides y engaños que, in extremis, impiden el casamiento de uno de los dos con un tercero, ora sea por sí solos (Dagoberto y Rosamira, Basilio y Quiteria), ora sea gracias a la labor de un intercesor (Pedro de Urdemalas en la de Clemente y Clemencia, Auristela en la de Carino y Leoncia y Solercio y Selviana). Tal clasificación no es baladí, en tanto en cuanto que los amores de Isabela y Andrea, conforme a su ambigüedad, pueden pertenecer a los dos grupos: no solo pueden haberse desposado en secreto, sino también haberlo certificado con el amplexo e, incluso, haberse quedado ella, como Cornelia y Feliciana, embarazada; mientras que el triunfo de su amor se obrará, como en los casos de Dagoberto y Rosamira y Basilio y Quiteria, gracias al embeleco ideado por Isabela, el cual será revalidado por Auristela, como don Quijote y ella misma habían hecho en los casos de Basilio y Quiteria y de las dos parejas de pescadores.

De modo que Isabela y Andrea se ven no una, sino en varias ocasiones, mientras que él permanece en la corte, antes de partir a Salamanca. De estas entrevistas resulta la confirmación de su amor y su reciprocidad, por lo que, hasta su resolución, tendrán que sortear los obstáculos que se lo impiden.

En efecto, el mismo día que Andrea se encamina a Salamanca, Alejandro Castrucho le anuncia a su sobrina que se prepare para partir de inmediato a Italia, donde se hará efectivo el concertado matrimonio con su primo. Isabela, rápida de pensamiento, escribe a Andrea para ponerle al tanto de la mala nueva y para explicarle la treta que ha ideado, consistente en detenerse a la altura de Luca a la espera de su llegada, fingiéndose endemoniada. Concluye su relato Isabela: 
Yo, por mi parte, he hecho lo que he podido: una legión de demonios tengo en el cuerpo, que lo mismo es tener una onza de amor en el alma, cuando la esperanza desde lejos le anda haciendo cocos. Esta es, señoras mías, mi historia; esta, mi locura; esta, mi enfermedad. Mis amorosos pensamientos son los demonios que me atormentan. (III, xx, 616-617)

Comenta Aurora Egido (1994: 265) que «la singular historia constituye un bonito revés a las teorías demonológicas sobre la magia que enredaban desde antiguo la cuestión amorosa y que habían servido de punto de discusión sobre la influencia del demonio y la posesión diabólica por tales causas». A nuestro modo de ver, sin embargo, la demonología amorosa del episodio apunta, no sin ironía, a la filografía platónica, tanto a la del Banquete, entreverando el mito del hombre esférico de Aristófanes en que el amor se concibe como el anhelo de encontrar la mitad perdida, la búsqueda de la unidad del ser, «llegar a ser uno solo de dos» (Platón, Banquete, 192e), con el de Diotima-Sócrates, en que el eros, el hijo de Poros (el Recurso) y de Penía (la Pobreza), se postula como un demonio o daimón, un ser de naturaleza intermedia que comunica el suelo con el cielo, el hombre con la divinidad; como a la del Fedro, en donde el amor se discierne como una locura, una posesión, un delirio, una manía, de inspiración divina, «que dijimos ser - recuerda Sócrates a Fedro- la más excelsa», «y al partícipe de esta manía, al amante de los bellos, se le llama enamorado» (Platón, Fedro, 265b y 249e). Así, ante una nueva demostración de Isabela, glosa el narrador: "porque se vea quién es el amor, pues hace parecer endemoniados a los amantes» (III, XXI, 617), y, ya al final, Auristela, en papel de sacerdotisa, al tender la mano Andrea a Isabel, pontificará: «bien se la puede dar, que para en uno son» (III, XXI, 623).

El fin de la narración de Isabela cierra el capítulo xx y da paso al xxi, el cual, como queda dicho, es una acción mostrada en directo en el presente de la novela. El devenir de la trama del episodio, a pesar de la distorsión cronológica provocada por el inicio in medias res, se dispone, pues, según el patrón clásico, de presentación, nudo y desenlace. De modo que lo que acontece en el capítulo XXI se corresponde con el desarrollo del nudo - la conversación de Isabela con Juan Bautista Marulo— y el desenlace — la llegada de Andrea-. Tanto la parte anterior del episodio como, sobre todo, la de este capítulo XxI presentan situaciones bastante similares a las de un planteamiento dramático, no solo por la planificación y puesta en escena de la secuencia en torno a la cama donde se halla recostada y atada Isabela así como por la continua entrada y salida de personajes de la estancia, sino especialmente por el magistral manejo de la palabra hablada por parte de Cervantes, del diálogo o dialogismo, siempre abierto, ambiguo, equívoco, original, polifónico e inacabado. Acaso no resulte excesiva esta contingencia sabiéndose, como se sabe, que existen afinidades de bulto entre la novela corta y la práctica teatral; no en vano Fernández de Avellaneda denominó a las Ejemplares "comedias en prosa» (Segundo tomo del ingenioso hidalgo don Quijote de la Mancha, p. 8), Lope de Vega, metido a novelliere, llegó a la conclu- 
sión de que «tienen las novelas los mismos preceptos que las comedias» (Novelas a Marcia Leonarda, p. 183), ${ }^{27}$ y los investigadores modernos no han parado de observar, tanto en algunos de los relatos de la colectánea cervantina como en varios de los episodios del Quijote, la novelización de ensayos dramáticos o la utilización de técnicas dramáticas en su elaboración. ${ }^{28}$

Mas la posibilidad de que existan elementos o rasgos que denotan una raigambre dramática no significa que su utilización y su función no estén puestos al servicio de una determinada estrategia narrativa, sino todo lo contrario. Por lo pronto, el capítulo Xxi se abre con un comentario ideológico del narrador sobre la acción contada que sirve no menos para reafirmar su control sobre la diégesis que para marcar el inciso que delimita lo acontecido con lo que resta por suceder en relación con la posición de los personajes principales del Persiles respecto de la historia episódica (e, igualmente, la del lector):

Priesa se daba la hermosa Isabela Castrucha a revalidar su demonio, y priesa se daban las cuatro, ya sus amigas, a fortalecer su enfermedad, afirmando con todas las razones que podían de que verdaderamente era el demonio el que hablaba en su cuerpo: porque se vea quién es el amor, que hace parecer endemoniado a los amantes. (III, XXI, 411)

Pues, efectivamente, si al principio las bellas peregrinas (y el lector) ocupaban la posición de espectadoras de una escena enigmática a tenor de su desconocimiento de los móviles de los personajes episódicos, toda vez que, por solidaridad femenina, se han involucrado en la historia y están al tanto de los pormenores, su posición experimenta un giro copernicano: ahora ellas (y el lector) se hallan en una posición de privilegio, tal, que les permite compartir y deleitarse, admirarse y emocionarse estéticamente de la pericia e donaire de Isabela (y del escritor) en el diseño de una treta en que se suspenden los límites entre la realidad y el fingimiento, entre las burlas y las veras, y en donde campan a sus anchas la anfibología y los cambios de efecto. No por casualidad, el narrador efectúa una llamada de atención al lector externo para que no se le pase el juego de la literatura desapercibido y para que se haga su cómplice, lo mismo que las cuatro heroínas - Auristela, Félix Flora, Ruperta y Constanza-, de Isabela: "Con éstas fue ensartando otras razones equívocas, conviene a saber, de dos sentidos, que de una manera las entendían sus secretarias y de otra los circunstantes: Ellas las interpretaban verdaderamente y, los demás,

27. Véase Muñoz Sánchez (2011, 2013a y 2013b).

28. Véanse, por ejemplo, Close (1981), Gilman (1993: 154-182), Martín Morán (1990: 89100), Montero Reguera (2003), Ynduráin (1966). Para el caso que nos ocupa, como hemos citado ya, es fundamental Zimic (2005: 179-185 y 215-228). 
como desconcertados disparates» (III, XXI, 618). ${ }^{29}$ Pero solo para advertirle que, como ellas, tendrá que interpretar derechamente lo que ocurre, leer entrelíneas y tomar partido libremente.

Hecha la pińa de las cinco damas, lógica si tenemos en cuenta que «lo que viene a continuación es la batalla de una joven, Isabela Castrucho, contra la necedad social de la época» (Nerlich 2005: 527), empieza el baile de entradas y salidas de personajes en el aposento. Los primeros en pasar son el médico y el padre de su amado, Juan Bautista Marulo. El doctor, dado que ya ha tratado con la enferma, es quien oficia de presentador, encareciendo la belleza de la endemoniada y la esperanza que tiene depositada en la arribada de Andrea, por cuanto su presencia coincidirá con el preciso instante en que el demonio abandone el cuerpo de Isabela. Resulta difícil discernir, por lo resbaladizo del contexto, el grado de conocimiento y de implicación que tiene el médico en el ardid de Isabela, si es uno de los burlados y engańados, como los sacerdotes y el tío, o si está al tanto del fingimiento, e, inclusive, de si la loca de Luca está o no embarazada. En todo caso, hechas las presentaciones, ocurre que Juan Bautista Marulo e Isabela se enzarzan en una conversación de doble filo, que es al mismo tiempo una suerte de relación intradiegética en virtud de la cual la noble hispano-italiana, según le va preguntando el padre de Andrea, le va poniendo al tanto de la relación que guarda con su hijo.

Es en este diálogo, sabroso y oblicuo al parigual, donde la loca de Luca muestra toda su ingeniosidad y picardía para aludir a los muchos galanes pisaverdes que pululan por la corte a la búsqueda y captura de la mujer más hermosa, cuyas razones y acciones hacen tanto mal a la república, entre los que se cuenta el hijo de su interlocutor, que es «más hermoso que santo y menos estudiante que galán» (III, XXI, 618). Quizá no esté de más recordar que los peregrinos, reducidos por aquel entonces a los amantes nórdicos y la familia del español Antonio, no detuvieron su andadura en Madrid auspiciados por el consejo de la vieja y estrafalaria peregrina de que «andaban en la corte ciertos pequeños que tenían fama de ser hijos de grandes, que, aunque pájaros noveles, se abatían al señuelo de cualquiera mujer hermosa, de cualquier calidad que fuese: que el amor antojadizo no busca calidades, sino hermosura» (III, VIII, 510). Esto es, Isabela — que parece tener un ducho conocimiento de la comedia de capa y espada, de ambiente urbano, repleta de galanteos, intrigas y enredos amorosos, en las que impera el ingenio y la traza, donde el amor y el interés son las fuerzas dominantes, y a la que ella parece emular a fin de conseguir sus propósitos - alude a un universo literario, cual es el de los caballeros galanes,

29. Recuérdese que Lope de Vega, en el Arte nuevo de hacer comedias en este tiempo (1609), aseguraba que «siempre el hablar equívoco ha tenido / y aquella incertidumbre anfibológica / gran lugar en el vulgo, porque piensa / que él solo entiende lo que el otro dice» (vv. 323-326). 
que de nuevo remite al universo cervantino de La entretenida $a^{30}$ y al de tantas historias en las que se perfila a un joven noble tan enamoradizo como antojadizo de los «que agora se usan", a quienes «antes les crujen los damascos, los brocados y otras ricas telas de que se visten, que la malla con que se arman» (Cervantes, Don Quijote, II, I, 693), al modo del don Fernando del Ingenioso hidalgo, del Rodolfo de La fuerza de la sangre, del Loaisa de El celoso extremeño, del hijo de los Duques del Ingenioso caballero. Puesto que, como el lector y sus secretarias saben, Isabela miente, no en su relación con Andrea, que efectivamente es una suerte de "putativo Ganimedes» o de "contrahecho Adonis» (III, XXI, 621), sino en el modo de producirse, habida cuenta de que fue ella quien hizo de pisaverde, de «mancebito cuellierguido" (Cervantes, Viaje del Parnaso, VIII, 433) atropellando el alma del estudiante de Luca.

La sagaz hispano-italiana, aprovechando la pregunta de Juan Bautista de dónde conoció a su hijo, vuelve a servirse de su saber teatral de la comedia urbana madrileña, en la que, además de en sus calles, paseos y jardines, la acción transcurría en los pueblos vecinos, con especial atención a los situados en el derrotero que unía Toledo con la Corte - como se cifra en el título la comedia de Tirso de Molina, Desde Toledo a Madrid (1626)—, para indicarle que lo conoció en Illescas. Pero también a su conocimiento de la literatura popular y el folclore, pues al pueblo toledano une la festividad de san Juan. Isabela, cierto, le dice a Juan Bautista Marulo que conoció a su hijo Andrea tal día en tal lugar. Tanto un referente como el otro remiten al amor: «Illescas [porque] es uno de los pueblos frecuentados por los comediógrafos del Siglo de Oro para situar los enredos amorosos de sus comedias", mientras que el día de San Juan, "dentro de una dimensión simbólico-folclórica, porque es el día más propicio para conocerse los enamorados» (Lozano-Renieblas 1998: 55 y 56-67). Un nítido ejemplo de ello lo constituye la historia de Clemente y Clemencia en Pedro de Urdemalas, con la que tantas afinidades ostenta nuestro episodio, en especial porque se desarrolla justo en el momento en que se conmemora la noche mágica del solsticio de verano. Pero Isabela, con su tono desenfadado y sesgado, no alude únicamente al lugar y al día del amor, sino también a otros elementos simbólicos, como coger guindas, de tradición erótica íntimamente relacionados con el deseo, la carnalidad y la cópula. De modo que Isabela, de manera críptica, podría estar revelando que su relación con Andrea ha llegado muy lejos, ${ }^{31}$ en marcado contraste con lo que había contado a sus cuatro confidentes. ¿Habla Isabela como fingida endemoniada o está diciendo la verdad? Difícil — tal vez innecesario—

30. En donde, en efecto, comenta el lacayo Ocaña, ante las quejas del padre de Marcela Osorio, que ha siso seducida por don Ambrosio: «QQue aquestos pisaverdes, / aquestos tiquimiquis / de encrespados copetes, / se anden a pescar bobas con embustes...!" (Cervantes, La entretenida, III, vv. 2835-2838).

31. Que es lo que dio pie a Maurice Molho (1994: 54) para sostener que Isabela y Andrea habían saboreado las mieles del amor y, de resultas, ella se había quedado embarazada. 
pronunciarse. Sin embargo, parece evidente que le está indicando al padre de Andrea que el matrimonio con su hijo es inexcusable.

Cierra esta escena el mismo personaje que la había comenzado: el médico, quien entiende perfectamente la oblicuidad de Isabela: «Todo lo sabes, malino —dijo el médico-; bien parece que eres viejo» (III, xxI, 620). Su dictamen enlaza con el comentario ideológico del narrador externo al principio del capítulo sobre el efecto demoníaco que provoca el amor en los amantes.

Un inciso narrativo efectuado por el narrador extradiegético, en su función rectora, sirve para indicar el tránsito de una secuencia escénica a otra, marcada por la arribada de nuevos personajes («estando en esto, que no parece sino que el mismo Satanás lo ordenaba, entró...» [III, xxI, 620]). Se trata de la entrada en escena de Alejandro Castrucho para anunciarle a su sobrina la noticia de la llegada de Andrea Marulo a Luca y a la posada, previo paso por su casa, donde ha sido puesto al tanto de todo. El tío, representante de los valores de la sociedad señorial y patriarcal dominante, es, en consecuencia, el más sabrosamente engañado; buena prueba de ello es la felicidad que muestra con el joven cuya llegada será su ruina.

Andrea, por su parte, «que era discreto y estaba prevenido, por las cartas que Isabela le envió a Salamanca, de lo que había de hacer si la alcanzaba en Luca» (III, XXI, 621), sigue la humorada de su amada y se presenta tan locamente endemoniado como ella, pues a fin de cuentas se aman los dos. «Sabiduría y locura o posesión demoníaca se confunden en este caso", comenta Aurora Egido (1994: 266), pues efectivamente Isabela y Andrea muestran tener una extraordinaria complicidad, marcada por la experiencia amorosa adquirida, y estar familiarizados con la doctrina erótica de Platón, que reconducen a la unión matrimonial y la inserción en el ciclo de la vida:

— ¿No lo ha de estar [loco] —dijo Isabela—, si me vee a mí? ¿No soy yo, por ventura, el centro donde reposan sus pensamientos? ¿`No soy yo el blanco donde asestan sus deseos?

—Sí, por cierto — dijo Andrea—; sí, que vos sois señora de mi voluntad, descanso de mi trabajo y vida de mi muerte. Dadme la mano de ser mi esposa, señora mía, y sacadme de esa esclavitud en que me veo a la libertad de verme debajo de vuestro yugo; dadme la mano, digo otra vez, bien mío, y alzadme de la humildad de ser Andrea Marulo a la alteza de ser esposo de Isabela Castrucho. Vayan de aquí fuera los demonios que quisieren estorbar tan sabroso nudo, y no procuren los hombres apartar lo que Dios junta.

—Tú dices bien, señor Andrea — respondió Isabela—, y, sin que aquí intervengan trazas, máquinas ni embelecos, dame esa mano de esposo y recíbeme por tuya. (III, xxI, 622)

Triunfo del amor, triunfo del deseo, triunfo del ingenio, triunfo de la inteligencia, triunfo de la libertad sobre la coerción social, triunfo del gusto de los hijos sobre la autoridad familiar en lo relativo a la elección del cónyuge, que Isabela y Andrea proclaman con orgullo, porque el «amor» solo puede «ser 
voluntario, y no forzoso» (Cervantes, La Galatea, III, 199). Triunfo de Isabela, "que es sin duda alguna una mujer, ayudada por otras cuatro mujeres, que, abiertamente, quiere decidir sobre su propio cuerpo y sobre su propia existencia social» (Nerlich 2005: 536), al punto de que «la única historia de toda la novela en que puede decirse que un personaje consigue lo que quiere gracias a su esfuerzo personal directo es la de la muy astuta y poco ejemplar Isabela Castrucho» (Pelorson 2003: 83).

La semejanza que manifiesta su caso con las historias de Dagoberto y Rosamira y de Basilio y Quiteria parece fuera de duda, en virtud de que también estas dos parejas idean una estratagema (la falsa acusación, el suicidio) que impide el casamiento de ella con el cónyuge elegido por el padre en su presencia. Son tres casos, por consiguiente, en los que, por medio de la astucia y el artificio, se transgrede las normas civil y religiosa del matrimonio dimanadas del Concilio de Trento. A ellas cabe añadir el matrimonio de Clemente y Clemencia, consumado asimismo mediante una treta, pergeñada por el proteico protagonista de la comedia, quien, además, convence al padre de ella, el alcalde Martín Crespo, con las siguientes palabras:

\author{
Nuestro amo, habéis de saber \\ que es merced particular \\ la que el cielo quiere hacer \\ cuando se dispone a dar \\ al hombre buena mujer; \\ y corre el mismo partido \\ ella, si le da marido \\ que sea en todo varón, \\ afable de condición, \\ más que arrojado, sufrido. \\ De Clemencia y de Clemente \\ se hará una junta dichosa, \\ que os alegre y os contente, \\ y quien lleve vuestra honrosa \\ estirpe de gente en gente, \\ y esta noche de San Juan \\ las bodas se celebrarán \\ con el suyo y vuestro gusto. \\ (Cervantes, Pedro de Urdemalas, I, vv. 470-487)
}

Esta fórmula es básicamente la misma que pone por justificación don Quijote en las bodas de Camacho: "Quiteria era de Basilio y Basilio de Quiteria, por justa y favorable disposición de los cielos» (Cervantes, Don Quijote, II, XXI, 878), y también el duque de Novara para aceptar la unión de su hija Rosamira con Dagoberto: «Si esto permite el cielo y lo consiente / ¿qué puedo yo hacer? Ello está hecho; / gócela en paz» (Cervantes, El laberinto de amor, III, 28752877). Aun más: es la que defiende Auristela, delante del cura que iba a oficiar 
los esponsales y de los padres, para trocar las dos parejas de pescadores: «Esto es lo que quiere el cielo [...] Esto, señores — prosiguió mi hermana [cuenta Periandro]—, es, como ya he dicho, ordenación del cielo, y gusto no accidental, sino propio destos venturosos desposados, como lo muestra la alegría de sus rostros y el sí que pronuncian sus lenguas» (II, x, 347). El círculo lo cierra, de nuevo, Auristela, pues - como hemos citado ya - cuando se dan la mano Isabela y Andrea vuelve a emitir la sentencia, pero esta vez sin disposición del cielo, no más que remitiendo al axioma del discurso de Aristófanes en el Banquete: «Bien se la puede dar [la mano], que para en uno son» (III, xxI, 623).

Estas cinco historias, en definitiva, demuestran, como aseveraba don Quijote,

que el amor y la guerra son una misma cosa, y así como en la guerra es cosa lícita y acostumbrada usar de ardides y estratagemas para vencer al enemigo, así en las contiendas y competencias amorosas se tienen por buenos los embustes y marañas que se hacen para conseguir el fin que se desea, como no sean en menoscabo y deshonra de la cosa amada. (Don Quijote, II, xxI, 878)

No obstante, se pueden estrechar aun más los vínculos entre las historias de Basilio y Quiteria y de Isabela y Andrea, puesto que su primer enlace se confirma con un segundo, luego de advertir el engaño, y en presencia de sacerdotes que certifican la validez del matrimonio.

El final festivo de la historia, preparado por la industria de Isabela, por la participación de Andrea y por la presencia de Auristela, Constanza, Félix Flora y Ruperta, deviene tragicómico por el súbito fallecimiento de Alejandro Castrucho ante la ignominia sufrida. Se trata, de algún modo, de una anticipación del final de la novela, por cuanto las bodas de Periandro y Auristela vendrán a coincidir con los funerales de Magsimino, el hermano mayor de él y prometido de ella. De hecho, independientemente de que hayan cogido o no los frutos del amor y de que el hermano de Andrea que aparece en el último momento para bautizarse sea o no el hijo de la pareja, la historia de Isabela y Andrea oficia de contraste realzador de la de Periandro y Auristela, ejemplifica en paralelo la de los protagonistas de la novela.

\section{Cierre: el último episodio de Cervantes}

Ignoramos la fecha en que Cervantes compuso el relato de la dama de verde, aunque los nexos que establece con otras obras suyas parece encaminarlo al periodo final de su carrera, ni si fue pensado como un texto independiente, adaptado para su inserción y acoplado después en el Persiles, o si fue redactado ad hoc para formar parte de la novela desde el principio. En cualquier caso, es el último episodio intercalado del conjunto de su prosa narrativa, y su lección estética no refleja sino el espíritu tan jovial como burlón, no menos inteligente que irónico de un autor dueño absoluto de los resortes de su arte, al que es innegable que le complace sobremanera mostrar el amor libre y natural de dos jóvenes y la autodeterminación de la mujer. 


\section{Bibliografía}

Alemán, Mateo, Guzmán de Alfarache, ed. Luis Gómez Canseco, Madrid, RAE, 2012.

Armstrong-Roche, Michael, Cervantes' Epic Novel. Empire, Religion and the Dream Life of Heroes in "Persiles», Toronto, Toronto University Press, 2009.

Bajtín, Mijail, Teoría y estética de la novela, trad. de Helena S. Kriúkova y Vicente Carranza, Madrid, Taurus, 1989.

Baquero Escudero, Ana Luisa, La intercalación de historias en la narrativa de Cervantes, Vigo, Academia del Hispanismo, 2013.

Canavaggio, Jean, Retornos a Cervantes, Nueva York, IDEA, 2014.

Cervantes, Miguel de, Don Quijote de la Mancha, ed. del Instituto Cervantes dirigida por Francisco Rico, Madrid, RAE, 2015.

-, La entretenida, en Comedias y tragedias, coord. Luis Gómez Canseco, ed. Ignacio García Aguilar, 2 vols., Madrid, RAE, 2015, I, 687-794.

—, La Galatea, eds. Juan Montero, F. J. Escobar Borrego y Flavia Gherardi, Madrid, RAE, 2014.

-, El laberinto de amor, en Comedias y tragedias, coord. Luis Gómez Canseco, ed. José Manuel Rico García, 2 vols., Madrid, RAE, 2015, I, 575-685.

-, Pedro de Urdemalas, en Comedias y tragedias, coord. Luis Gómez Canseco, ed. Adrián J. Sáez, 2 vols., Madrid, RAE, 2015, I, 795-906.

—, Los trabajos de Persiles y Sigismunda, ed. Carlos Romero Muñoz, Madrid, Cátedra, 2004 ( $5^{\mathrm{a}}$ ed.).

—, Viaje del Parnaso y poesías sueltas, eds. J. Montero Reguera, F. Romo Feito y M. Cuiñas Gómez, Madrid, RAE, 2016.

Close, Anthony, "Characterization and Dialogue in Cervantes's 'Comedias en prosa'”, Modern Language Review, LXXVI (1981), 338-356.

De Armas Wilson, Diana, Allegories of Love: Cervantes's "Persiles and Sigismunda», Princeton, Princeton University Press, 1991.

Deffis de Calvo, Emilia I., Viajeros, peregrinos y enamorados. La novela española de peregrinación del siglo XVII, Pamplona, Eunsa (Anejos de Rilce, 28), 1999.

Egido, Aurora, Cervantes y las puertas del sueño, Barcelona, PPU, 1991.

Fernández de Avellaneda, Alonso de, Segundo tomo del ingenioso hidalgo don Quijote de la Mancha, ed. Luis Gómez Canseco, Madrid, RAE (Anejos BCRAE), 2014.

GHia, Walter, "Individuo e modelli normativi nel Persiles», Anuario de Estudios Cervantinos, XI. El pensamiento literario del último Cervantes: del «Parnaso» al "Persiles», Vigo, Academia del Hispanismo, (2015), 289-302.

Gilman, Stephen Gilman, La novela según Cervantes, trad. de Carlos Ávila, México, Fondo de Cultura Económica, 1993.

Hasbrouck, Michael D., «Posesión demoniaca, locura y exorcismo en el Quijote», Cervantes, XII (1992), 117-126. 
López «Pinciano», Alonso, Philosophia antigua poética, en Obras completas I, ed. José Rico Verdú, Madrid, Castro, 1998.

Lozano Renieblas, Isabel, Cervantes y el mundo del "Persiles», Alcalá de Henares, Centro de Estudios Cervantinos, 1998.

—, Cervantes y los retos del "Persiles», Salamanca, SEMYR, 2014.

Márquez Villanueva, Francisco, Personajes y temas del "Quijote», Madrid, Taurus, 1975.

—, Trabajos y días cervantinos, Alcalá de Henares, CEC, 1995.

Martín Morán, José Manuel, El «Quijote» en ciernes, Turín, Edizione Dell’Orso, 1990.

Molno, Maurice, Préface à Miguel de Cervantes, Les travaux de Persille et Sigismonde, histoire septentrionale, París, José Corti, 1994, 7-69.

Montero Reguera, José, "La Gitanilla, de novela a comedia», ed. I. Carrasco Cantos, El mundo como escritura. Estudios sobre Cervantes y su época, Málaga, Universidad de Málaga, 2003, 123-138.

Muñoz SÁnchez, Juan Ramón, «Tradición e innovación en el episodio de Ruperta, "la bella matadora" del Persiles", Revista de Filología Española, LXXXVII (2007), 103-130.

—, “Los vírgenes esposos del Persiles”: el episodio de Renato y Eusebia», Anales Cervantinos, XL (2008), 205-228.

—, "Escribía / después de haber los libros consultado": a propósito de Lope de Vega y los novellieri, un estado de la cuestión (con especial atención a la relación con Giovanni Boccaccio), parte I», Anuario de Lope de Vega. Texto, literatura, cultura, XVII (2011), 85-106.

—, De amor y literatura: hacia Cervantes, Vigo, Academia del Hispanismo, 2012.

-, "Yo he pensado que tienen las novelas los mismos preceptos que las comedias": De Boccaccio a Lope de Vega», coords. Isabel Colón Calderón y David González Ramírez, Estelas del "Decamerón» en Cervantes y la literatura del Siglo de Oro, Málaga, Universidad de Málaga, 2013a, 163-186

—, "Escribía / después de haber los libros consultado": a propósito de Lope de Vega y los novellieri, un estado de la cuestión (con especial atención a la relación con Giovanni Boccaccio), parte II», Anuario de Lope de Vega. Texto, literatura, cultura, XIX (2013b), 116-149.

—, "Reflexiones sobre Los trabajos de Persiles y Sigismunda, historia setentrional», Anales Cervantinos, XLVII (2015a), 249-288.

—, «El episodio de Feliciana de la Voz (Persiles, III, 2-5) en el conjunto de la obra de Cervantes», Artifara, 15 (2015b), 157-183.

Nerlich, Michael, El «Persiles» descodificado o la «Divina comedia» de Cervantes, trad. de Jesús Munárriz, Madrid, Hiperión, 2005.

Pelorson, Jean-Marc, El desafío del "Persiles», Toulouse, Presses Universitaires du Mirail (Anejos de Criticón, 16), 2003, 7-93.

Percas de Ponseti, Helena, Cervantes y su concepto del arte, 2 vols., Madrid, Gredos, 1975. 
Platón, Diálogos, III. Fedón, Banquete, Fedro, eds.C. García Gual, M. Martínez Hernández y E. Lledó Ínigo, Madrid, Gredos, 1997.

Redondo, Agustín, «El Persiles: 'libro de entretenimiento' peregrino», ed. A. Villar Lecumberri, Peregrinamente peregrinos. Actas del V Congreso Internacional de la Asociación de Cervantistas, Alcalá de Henares, Asociación de Cervantistas, 2004, 67-102.

Rey Hazas, Antonio, y Sevilla Arroyo, Florencio, «Introducción a Cervantes, Los trabajos de Persiles y Sigismunda», eds. F. Sevilla Arroyo y A. Rey Hazas, Madrid, Alianza (Obra Completa, vol. 18), 1999, I-LXI.

Romero Muñoz, Carlos, "Introducción a Cervantes, Los trabajos de Persiles y Sigismunda», ed. Carlos Romero Muñoz, Madrid, Cátedra, 2004 (5 ed.), 11-60.

Serés, Guillermo, La transformación de los amantes, Barcelona, Crítica, 1996.

Scaramuzza Vidoni, Mariarosa, Deseo, imaginación, utopia en Cervantes, Roma, Bulzoni Editore, 1998.

Vega y Carpio, Lope de, Arte nuevo de hacer comedias, ed. Evangelina Rodríguez, Madrid, Castalia, 2011.

-, Novelas a Marcia Leonarda, ed. Antonio Carreño, Madrid, Cátedra, 2011 ( $2^{\mathrm{a}}$ ed.).

YNduráin, Domingo, "Rinconete y Cortadillo. De entremés a novela», Boletín de la Real Academia Española, XLVI (1966), 321-333.

Zimic, Stanislav, Cuentos y episodios del "Persiles». De la isla bárbara a una apoteosis del amor humano, Pontevedra, Mirabel Editorial, 2005. 
